\title{
Tribological Properties and Microstructure of Electroless Nickel Coatings Reinforced with Nanoparticles
}

\author{
Julieta Kaleicheva \\ Faculty of Industrial Technology \\ Technical University of Sofia \\ Sofia, Bulgaria \\ jkaleich@tu-sofia.bg
}

\author{
Zdravka Karaguiozova \\ Space Research and Technology Institute \\ Bulgarian Academy of Sciences \\ Sofia, Bulgaria \\ karazuzi@yahoo.com
}

\author{
lentin Mishev \\ Faculty of Industrial Technology \\ Technical University of Sofia \\ Sofia, Bulgaria \\ v_mishev@tu-sofia.bg
}

\begin{abstract}
Composite nickel coatings composed of $\mathrm{Ni}$; Ni + TiN are studied. The method for elecrtroless nickel deposition EFFTOM-NICKEL with TiN nanosized strengthening particles $(50 \mathrm{~nm})$ is applied. The coatings are deposited on austempered ductile iron (ADI) samples. The composition of cast iron samples is: $\mathrm{Fe}-3,63 \mathrm{C}-2,59 \mathrm{Si}$ 0,30Mn-0,010S-0,034P-0,53Cu wt. \%. The samples are put under isothermal hardening at $9^{900^{\circ}} \mathrm{C}$ for an hour and isothermal retention at $290{ }^{\circ} \mathrm{C}$ for 2 hours with the aim to receive a lower bainite structure. The wear resistance experimental testing is carried out using TaberAbraser test machine by disk to disk classical method. The microstructure observations of the coatings and padding are performed using an optical microscope GX41 OLIMPUS also the coatings' microhardness by Knoop Method is examined. The wear resistance, microstructure, thickness and microhardness of the as plated and thermally processed at $290^{\circ} \mathrm{C}$ for 6 hours coatings are defined.
\end{abstract}

Keywords - titanium nitride, electroless nickel coating, wear resistance, microhardness, lower bainite.

\section{INTRODUCTION}

The simplicity of electroless plating technology and its ability to produce high quality coatings is the reason for their popularity in surface modification and significant impact on numerous industrial applications. Nickel is a preferred metal in this method for producing coatings. Nickel coatings have excellent corrosion and wear resistance and high microhardness [1]. The necessity for the materials surface properties improvement launched the idea of the various second phase particles incorporation in the electroless nickel coatings in the 1960s [2] and led to the development of electroless nickel composite coatings. The electroless composite coating is formed by the codeposition and settlement of particles on the surface of the work piece, and the subsequent envelopment of these particles by the matrix material as it is deposited. There is no molecular bonds between the particles and metal matrix [3]. The soft or hard particles are used for the co-deposition process. Several factors influence their incorporation in the electroless Ni-P matrix including, particle size and shape, relative density of the particle, particle charge, inertness of the particle, the concentration of the particles in the plating bath, the method and degree of the agitation, the compatibility of the particle with the matrix, and the orientation of the part being plated [4]. In [5] the authors outline the improvement in surface properties offered by such composite coatings and their significant impact on numerous industrial applications securing a more prominent place in the surface engineering of the metals and alloys. Thus composite coatings constitute a new class of materials which are mostly used for mechanical and tribological applications. Among these materials, nickel deposits incorporating hard ceramic particles such as silicon carbide $\mathrm{SiC}$, combine anti-corrosion properties (due to the presence of nickel), with mechanical and tribological performances (due to the presence of particles of $\mathrm{SiC}$ ). [6] studying the mechanical (hardness) and tribological (friction resistance and wear) properties of the co-deposits concludes that increasing the size or the rate of $\mathrm{SiC}$ particles incorporated lead to an increase in both the hardness of the films and friction coefficient when sliding against a steel ball. Author's research [7] on the mechanism of incorporation of reinforced $\mathrm{ZrO} 2$, $\mathrm{TiO} 2$, and $\mathrm{Al} 2 \mathrm{O} 3$ particles on 6061 aluminium alloy and on the effect of different composites on the mechanical properties of the deposit such as hardness and wear resistance proved once again that the reinforced particles as well as the heat treatment provide satisfactory improvement in hardness and wear resistance of the deposits.

Improving the properties of low-cost materials is a good opportunity to expand their application areas. Electroless nickel coatings are such an opportunity for the improvement of the cast irons surface properties [8]. The study in this work utilized electroless nickel (EN) and cathodic arc deposition (CAD) technologies with lower processing temperature to treat austempered ductile iron (ADI). The test results show that microstructures of ADI did not deteriorate after EN and CAD surface treatments. Moreover, both the EN and CAD-DLC (diamond-like carbon) coatings are identified to be amorphous type and they could be well deposited on the ADI substrate. The duplex coated DLC/EN-ADI show the highest hardness (1312 HV0.05), followed by DLC-ADI (1088 HV0.05),

Print ISSN 1691-5402 Online ISSN 2256-070X http://dx.doi.org/10.17770/etr2019vol3.4182 (C) 2019 Julieta Kaleicheva, Zdravka Karaguiozova, Valentin Mishev. Published by Rezekne Academy of Technologies.

This is an open access article under the Creative Commons Attribution 4.0 International License. 
EN-ADI (409 HV0.05) and then uncoated ADI (396 HV0.05). In the case of corrosion resistance, all the coated specimens are better than that of the uncoated one in $3,5 \mathrm{wt} . \% \mathrm{NaCl}$ aqueous solution, and the sequence is DLC/EN-ADI > EN-ADI > DLC-ADI >ADI.

In recent years, physical vapor deposition (PVD) technique using lower processing temperature has been widely adopted to coat various films, such as diamondlike carbon (DLC), CrN, TiN etc., on the engineering material for surface modification. In particular, DLC film possesses excellent mechanical properties such as high hardness and low friction coefficient. Electroless nickel (EN), another lower temperature coating process, has also a wide field of application such as the industrial components and machine parts. The purpose of the study [9] is to investigate the effect of EN and PVD-DLC surface coatings on mechanical behaviors of ADI, especially the tensile and fatigue properties.

This study is focused on the investigation of nanosized strengthening TiN particles influence on the tribological properties, microstructure and microhardness of composite nickel coatings, deposited on austempered ductile iron (ADI) samples, copper alloyed.

\section{MATERIALS AND METHODS}

\section{A. Materials and heat treatment}

The EFTTOM-NICKEL technology for electroless nickel plating developed at TU of Sofia [10] is applied to obtain composite coatings with nanosized strengthening TiN particles $(50 \mathrm{~nm})$.

The composite coatings are deposited on copper alloyed austempered ductile iron (ADI) samples.The composition of cast iron samples is: Fe-3,63C-2,59Si-0,30Mn-0,010S$0,034 \mathrm{P}-0,53 \mathrm{Cu} w t . \%$. The cast iron samples are put under prior to the plating process. The heat treatment consists of heating at $900^{\circ} \mathrm{C}$ for an hour and subsequent isothermal retention at $290^{\circ} \mathrm{C}$ for 2 hours. The result is to obtain ductile cast iron with a lower bainite structure (Fig. 1).

Two types of coatings are investigated: electroless nickel coating $\mathrm{Ni}$ and composite nickel coating with nanosized titanium nitride $\mathrm{Ni}+\mathrm{TiN}$ (Table 1).

Some of the samples are heat treated at $290^{\circ} \mathrm{C}$ for 6 hours after coating deposition for the coatings' adhesion improvement and microhardness increase.

The microstructure of the padding and the coatings and the coatings' thickness are defined by means of an optical metallographic microscope GX41 OLIMPUS. The microhardness testing of the coatings is examined by Knoop method under 20g load (Table1).

Table 1 Composition, heat treatment, MICROHARDNESS AND THICKNESS OF COATINGS

\begin{tabular}{|c|c|c|c|c|}
\hline № & Composition & $\begin{array}{c}\text { Heat } \\
\text { treatment }\end{array}$ & $\begin{array}{c}\text { Microhardness } \\
\text { HK0,02 }\end{array}$ & $\begin{array}{c}\text { Thickness, } \\
{[\mu \mathrm{m}]}\end{array}$ \\
\hline 1 & $\mathrm{Ni}$ & - & 538 & 10 \\
\hline 2 & $\mathrm{Ni}$ & $290^{\circ} \mathrm{C}, 6 \mathrm{~h}$ & 950 & 10 \\
\hline 3 & $\mathrm{Ni}+\mathrm{TiN}$ & - & 588 & 8 \\
\hline 4 & $\mathrm{Ni}+\mathrm{TiN}$ & $290^{\circ} \mathrm{C}, 6 \mathrm{~h}$ & 1020 & 8 \\
\hline
\end{tabular}

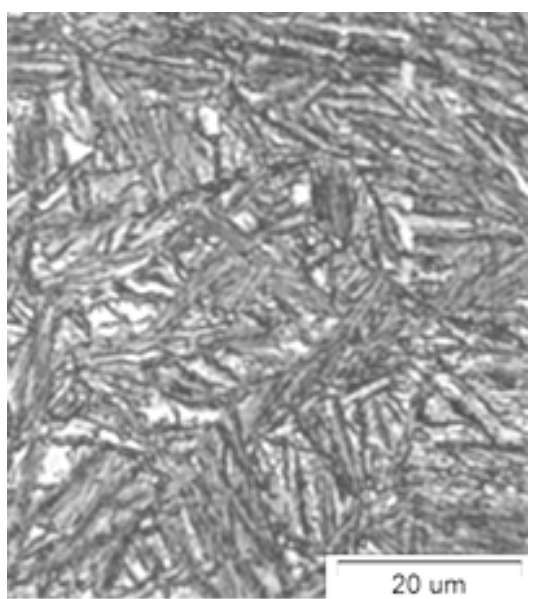

Fig.1. Microstructure of the austempered ductile iron sample without coating

B. Device and method for wear resistance testing

The experiments on the wear resistance of nickel coatings are carrying out using a classic design "backto-back" disc on a TABER ABRASER test machine 503, modified in accordance with the developed by the authors' method. The device design is shown on Fig. 2.

The ring shaped sample 1 (solid) with a coating 2 is fixed on a horizontal disc 3 , which is moved by an electric motor 4 with a constant angular speed w. The antibody 5 is a disc from a special abrasive material CS10. The desire normal load $\mathrm{P}$ in the contact surface is set through a mounted in the antibody axle, which is operated by a special device. In this way the body 1 and antibody 5 are fixed on two cross axes. Upon the constant angular speed $\mathrm{w}=$ const of the sample 1 and upon constant nominal contact pressure $\mathrm{Pa}=$ const the friction in the contact surface K keeps a constant rotation speed of the antibody 5 .

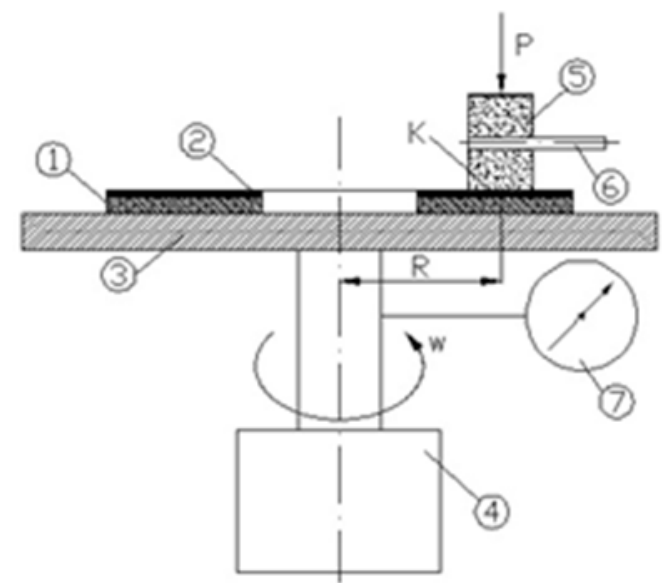

Fig.2. TABER-ABRASER test machine

The test method description:

- All samples with the same ring shape and size, before the coating process are subjected to a mechanical treatment, namely grinding and polishing to ensure an equal surface roughness $\mathrm{Ra}=0,4 \mu \mathrm{m}$. This is a binding requirement for the reliability of the wear testing, because the electroless coatings "copy" the samples surface by the plating process.

- When choosing the integral parameter "massive wear" the weight of the sample is weighed before 
and after a determinate number of the disc rotation by an analytical balance WPS 180/C/2 précised to $0,1 \mathrm{mg}$. The samples are treated with a special solution to neutralize the static electricity before the weighting.

- Sample 1 is fixed on a horizontal disc 3 and by the lever system the desire normal load $\mathrm{P}$ is set. The friction road $\mathrm{L}$ is determined by the number of cycles $\mathrm{N}$, accounted with a cyclometer 7 .

Test basic parameters are:

- absolute massive wear $\mathrm{m}[\mathrm{mg}]$ - this is a coating lost weight in the process of the wear, estimated as a difference between the samples weight before and after the appointed number of friction cycles.

- speed of massive wear $\dot{\mathrm{m}}[\mathrm{mg} / \mathrm{min}]$ - the lost weight of the coating for a minute.

- intensity of wear i - this is the lost coating thickness for an one friction cycle. The result is a dimensionless number, which could be calculated by the formula having in mind the lost weight:

$$
i=\frac{m}{\rho \cdot A a \cdot L}
$$

where:

- $\rho$ is the coating density $-\rho=7,8.10^{3}[\mathrm{~kg} / \mathrm{m} 3]$;

- Aa is the nominal interaction contact surface $=26,10^{-6}[\mathrm{~m} 2]$;

Aa

- $\mathrm{L}$ is the friction road, estimated by the number of cycles N:

$$
\mathrm{L}=2 . \pi \cdot \mathrm{R} \cdot \mathrm{N}
$$

where:

$-\mathrm{R}$ is the distance between the rotation axis of the bearing disc and the mass center of the contact place between the sample 1 and the contra body 5 (Fig. 1).

- absolute wear resistance I - this is a dimensionless number and is determined as a reciprocal value of the wear intensity, namely

$$
I=\frac{1}{i}=\frac{\rho \cdot A a \cdot L}{m}
$$

- nominal contact pressure $\mathrm{Pa},\left[\mathrm{N} / \mathrm{cm}^{2}\right]$ is the normal load, per the contact interaction surface Aa, i.e.

$$
P a=\frac{P}{A a}
$$

- comparative index of wear resistance eie what means the ratio between the wear resistance of the tested sample Ii and the wear resistance of a sample-standard Ie, i.e it is a dimensionless number, indicating how many times the wear resistance of the tested sample is higher compared to the sample-standard under the same contact interaction conditions:

$$
\varepsilon_{i e}=\frac{I_{i}}{I_{e}}
$$

The parameters of the contact interaction are presented in Table 2.
Table 2 Test Parametars

\begin{tabular}{|c|c|}
\hline $\begin{array}{c}\text { Nominal contact surface } \\
A_{a},\left[\mathrm{~m}^{2}\right]\end{array}$ & $26.10^{-6}$ \\
\hline $\begin{array}{c}\text { Nominal contact pressure } \\
P a,\left[\mathrm{~N} / \mathrm{cm}^{2}\right]\end{array}$ & 47,15 \\
\hline $\begin{array}{c}\text { Average speed of sliding } \\
V,[\mathrm{~cm} / \mathrm{s}]\end{array}$ & 17,90 \\
\hline
\end{tabular}

\section{RESUlTS AND DISCUSSION}

The coatings' thickness is between $8 \div 10 \mu \mathrm{m}$ (Table 1). The microhardness HK 0,02 test results of the coatings are presented in Table 1. The heat treatment of the coatings at $290^{\circ} \mathrm{C}$ for 6 hours leads to the coatings' microhardness twice increase.

Electroless Ni-coatings show amorphous structure in an as-plated state. The coatings' structure becomes crystalline after heat treatment at $290 \mathrm{oC}, 6 \mathrm{~h}$. The diffraction patterns of the samples prove the presence of Ni3P phase in the coatings' structure [12].The heat treatment at $290 \mathrm{oC}, 6 \mathrm{~h}$ leads to a crystal formation of Ni3P phase, which is dispersed and increases the microhardness of the coatings [11], [12]. The introduced nano- and microparticles in coatings deposited by various methods further increase their microhardness [13].

The coatings' microstructure appears as a white strip following the sample relief (Figs 3 and 4). The padding microstructure of the cast iron, obtained at a low temperature isothermal retention in the bainitic field consists of a lower bainite (Figs 1, 3 and 4).

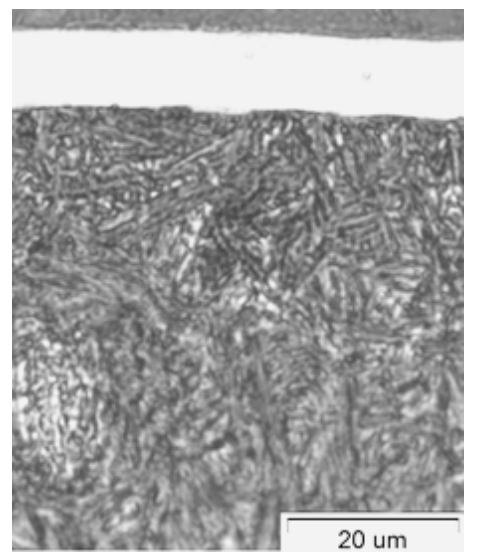

Fig.3. Microstructure of the austempered ductile iron sample with coatings $\mathrm{Ni}$ after heat treatment at $290^{\circ} \mathrm{C}, 6 \mathrm{~h}$

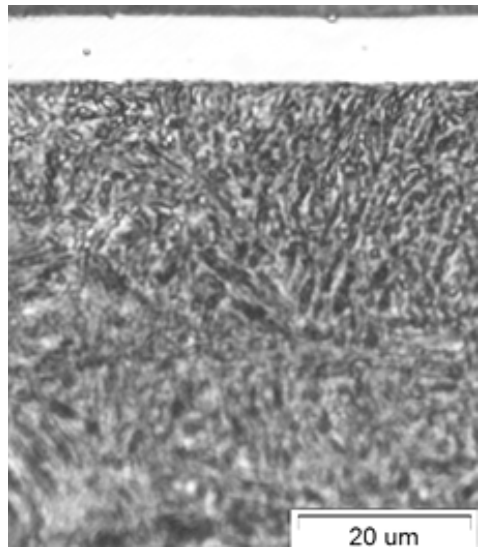

Fig.4. Microstructure of the austempered ductile iron sample with coating $\mathrm{Ni}+\mathrm{TiN}$ after heat treatment at $290^{\circ} \mathrm{C}, 6 \mathrm{~h}$ 
The experimental results received for the massive wear $m$ for the different coatings during the contact interaction are presented in Table 3.

TABLE 3 MASSIVE WEAR VARIATION IN TIME.

\begin{tabular}{|c|c|c|c|c|c|c|}
\hline № & $\begin{array}{c}2,5 \\
{[\mathrm{~min}]}\end{array}$ & $\begin{array}{c}5 \\
{[\mathrm{~min}]}\end{array}$ & $\begin{array}{c}7,5 \\
{[\mathrm{~min}]}\end{array}$ & $\begin{array}{c}10 \\
{[\mathrm{~min}]}\end{array}$ & $\begin{array}{c}12,5 \\
{[\mathrm{~min}]}\end{array}$ & $\begin{array}{c}15 \\
{[\mathrm{~min}]}\end{array}$ \\
\hline 1 & 3,2 & 5,1 & 6,0 & 6,7 & 7,9 & 8,9 \\
\hline 2 & 3,8 & 4,7 & 6,9 & 8,0 & 9,8 & 10,5 \\
\hline 3 & 2,7 & 3,8 & 4,3 & 5,3 & 6,0 & 6,9 \\
\hline 4 & 1,5 & 2,8 & 4,0 & 4,6 & 4,9 & 5,2 \\
\hline
\end{tabular}

The experimental results received for the massive wear rate $\dot{m}$ dependence on the friction road $\mathrm{L}$ for the different coatings are presented in Table 4.

TABLE 4 MASSIVE WEAR RATE VARIATION IN FRICTION ROAD

\begin{tabular}{|c|c|c|c|c|c|c|}
\hline № & $\begin{array}{c}26,85 \\
{[\mathrm{~m}]}\end{array}$ & $\begin{array}{c}53,70 \\
{[\mathrm{~m}]}\end{array}$ & $\begin{array}{c}80,55 \\
{[\mathrm{~m}]}\end{array}$ & $\begin{array}{c}107,4 \\
{[\mathrm{~m}]}\end{array}$ & $\begin{array}{c}134,25 \\
{[\mathrm{~m}]}\end{array}$ & $\begin{array}{c}161,1 \\
{[\mathrm{~m}]}\end{array}$ \\
\hline 1 & 1,28 & 1,02 & 0,80 & 0,67 & 0,63 & 0,59 \\
\hline 2 & 1,52 & 0,94 & 0,92 & 0,80 & 0,78 & 0,70 \\
\hline 3 & 1,08 & 0,76 & 0,57 & 0,53 & 0,48 & 0,46 \\
\hline 4 & 0,60 & 0,56 & 0,53 & 0,46 & 0,39 & 0,35 \\
\hline
\end{tabular}

Table 5 presents experimental results of the coatings' massive wear $m$ in contact interaction $\mathrm{t}=15 \mathrm{~min}$, the massive wear rate $\dot{m}$, also the wear intensity value $i$ and absolute wear resistance $I$. The samples' wear intensity $i$ and wear resistance $I$ are calculated at the friction road $\mathrm{L}=161,1[\mathrm{~m}]$.

TABLE 5 WEAR INTENSITY AND WEAR RESISTANCE IN FRICTION ROAD L $=161,1 \mathrm{M}$.

\begin{tabular}{|c|c|c|c|c|}
\hline № & $\begin{array}{c}\boldsymbol{m} \\
{[\mathbf{m g}]}\end{array}$ & $\begin{array}{c}\dot{\mathrm{m}} \\
{[\mathbf{m g} / \mathbf{m i n}]}\end{array}$ & $\begin{array}{c}\text { Wear } \\
\text { intensity } \\
\boldsymbol{i}\end{array}$ & $\begin{array}{c}\text { Wear } \\
\text { resistance } \\
\boldsymbol{I}\end{array}$ \\
\hline 1 & 8,9 & 0,59 & $2,72 \cdot 10^{-7}$ & $0,37.10^{7}$ \\
\hline 2 & 10,5 & 0,7 & $3,2 \cdot 10^{-7}$ & $0,31.10^{7}$ \\
\hline 3 & 6,9 & 0,46 & $2,11.10^{-7}$ & $0,47.10^{7}$ \\
\hline 4 & 5,2 & 0,34 & $1,6 \cdot 10^{-7}$ & $0,63 \cdot 10^{7}$ \\
\hline
\end{tabular}

The analysis of the wear resistance value (Fig .5) shows the sample 4 with $\mathrm{Ni}+\mathrm{TiN}$ coating with heat treatment at $290^{\circ} \mathrm{C}, 6 \mathrm{~h}$ possesses higher wear resistance $\left(I=0,63 \cdot 10^{7}\right)$ than this one of the sample 3 with the same coating but without heat treatment $\quad\left(I=0,47 \cdot 10^{7}\right)$. The measured higher microhardness of the $\mathrm{Ni}+\mathrm{TiN}$ coating with heat treatment at $290^{\circ} \mathrm{C}, 6 \mathrm{~h}(1020 \mathrm{HK} 0,02)$ compared to this one of the same coating without heat treatment $(588 \mathrm{HK} 0,02)$ corresponds to higher wear resistance (Table 1 and Fig. 5). The lack of correlation between the microhardness and wear resistance of the coatings of pure $\mathrm{Ni}$ (samples 1 and 2) could be attributed to the low adhesion between the coating and the padding This could be explained with the graphite presence in the iron microstructure.

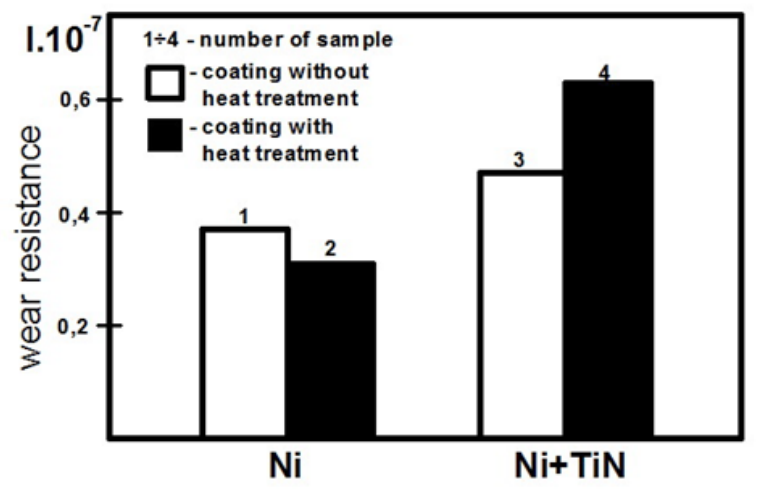

Fig.5. Wear resistance I of the coatings composition Ni (samples 1 and 2) and composition $\mathrm{Ni}+\mathrm{TiN}$ (samples 3 and 4), deposited on the austempered ductile iron samples.

\section{Conclusions}

It is found out that the electroless nickel coatings' microhardness with composition nickel $\mathrm{Ni}$ and nickel + nanosized titanium nitride $(50 \mathrm{~nm}) \mathrm{Ni}+\mathrm{TiN}$ deposited on austempered ductile iron samples is twice higher after heat treatment at $290^{\circ} \mathrm{C}, 6 \mathrm{~h}$ than this one of the coatings without heat treatment.

It is found that heat treated at $290^{\circ} \mathrm{C}, 6 \mathrm{~h}$ composite nickel coatings composition nickel + nanosized titanium nitride $(50 \mathrm{~nm}) \mathrm{Ni}+\mathrm{TiN}$ posses $34 \%$ higher wear resistance than this one of the same coatings without heat treatment.

\section{REFERENCES}

1. F. Mindivan, H. Mindivan and C. Darcan, "Electroless Ni-B Coating of Pure Titanium Surface for Enhanced Tribocorrosion Performance in Artificial Saliva and Antibacterial Activity," Tribology in Industry, vol. 39, No. 2, pp. 270-276, 2017, doi: 10.24874/ti.2017.39.02.15

2. W. Metzger and Th. Florian, "The Deposition of Dispersion Hardened Coatings by Means of Electroless Nickel," The Int. Journal of Surf. Eng. and Coatings, vol. 54, issue 1, pp. 174-177, 1976.

3. F.N. Hubbell, "Chemically Deposited Composites-A New Generation of Electroless Coatings," The Int. Journal of Surf. Eng. and Coatings, vol. 56, issue 1, pp. 65-69, 1978.

4. W.F. Sharp, "Properties and applications of composite diamond coatings," Wear, vol. 32, issue 3, pp. 315-325,1975.

5. J. Balaraju, S. Narayanan and S. Seshadri, "Electroless Ni-P composite coatings," Journal of Appl. Electrochemistry, vol. 33, issue 9, pp 807-816, 2003.

6. A. Grosjeana, M. Rezrazia, J. Takadoumb and P. Bercota "Hardness, friction and wear characteristics of nickel-SiC electroless composite deposits," Surf. and Coatings Tech., vol. 137, issue 1, pp. 92-96, 2001.

7. Z Abdel Hamid and M.T. Abou Elkhair, "Development of electroless nickel-phosphorous composite deposits for wear resistance of 6061 aluminum alloy," Mat. Lett., vol. 57, issue 3, pp. 720-726, 2002.

8. Cheng-Hsun Hsu, Jung-Kai Lu and Rung-Jie Tsai, "Characteristics of duplex surface coatings on austempered ductile iron substrates," Surf. and Coat. Tech., vol. 200, issues 20-21, pp. 5725-5732, 2006.

9. Cheng-Hsun Hsu, Jung-Kai Lu and Rung-Jie Tsai, "Effects of low-temperature coating process on mechanical behaviors of ADI," Mat. Sc. and Eng., A, vol. 398, issues 1-2, pp. 282-290, 2005

10. G. Gavrilov and C. Nicolov, Electroless Nickel and Composite Coatings. Sofia: Tehnika, 1985.

11. Z. Karaguiozova, J. Kaleicheva, V. Mishev and G. Nikolcheva, "Enhancement in the tribological and mechanical properties of electroless Nickel-nanodiamond coatings plated on iron," Tribology in Industry, vol. 39, No 4, pp. 444-451, 2017, doi: 10.24874/ti.2017.39.04.03

12. A. Mukhopadhyay, S. Duari, T.K. Barman and P. Sahoo, "Evaluation of Tribological Properties and Optimization of Electroless Ni-P-W Coating under Dry Condition using Grey Fuzzy Analysis," Tribology in Industry, vol. 39, No. 1, pp. 50-62, 2017, doi: 10.24874/ti.2017.39.01.06

13. T. Simeonova, M. Tongov and G. Avdeev, "Microstructure and properties of NiCrBSiC Overlay Coatings Deposited By The Plasma Scanning Process,"WIT Trans.on the Built Env. vol. 137, pp. 553-564, dos: 10.2495/HPSM140511 